\title{
Pengaruh Pola Komunikasi Organisasi, Loyalitas Karyawan Dan Iklim Organisasi Terhadap Produktivitas Kerja Organisasi Pada Pondok Pesantren Al-Munawwarah Di Kota Pekanbaru
}

\author{
Ramarni \\ Program Studi Pascasarjana Ilmu Administrasi Publik Universitas Riau
}

Korespondensi : ramarni@gmail.com

\begin{abstract}
Abstrak
Penelitian ini bertujuan untuk mengetahui dan menganalisis;pengaruh pola komunikasi organisasi, loyalitas karyawan dan iklim organisasi terhadap produktivitas kerja organisasi pada Pondok Pesantren Al-Munawwarah. Jenis penelitian ini adalah penelitian kuantitatif, dengan menggunakan metode survey. Metode survey merupakan metode dalam sebuah penelitian yang informasinya dikumpulkaan dari beberapa sampel dengan penyajian hasil penelitian dalam bentuk angka-angka atau statistic. Penelitian ini menggunakan Structural Equation Model (SEM) dengan alat analisis data untuk pengujian hipotesis adalah Partial Least Square (PLS) menggunakan aplikasi perangkat lunak SmartPLS ver 2.0 M3. PLS merupakan metode analisis yang powerful karena dapat diterapkan pada semua skala data, tidak membutuhkan banyak asumsi dan ukuran sampel tidak terlalu besar.berdasarkan hasil penelitian menunjukkan adanya pengaruh yang signifikan antara pola komunikasi organisasi, loyalitas karyawan dan iklim organisasi terhadap produktivitas kerja organisasi pada Pondok Pesantren Al-Munawwarah.
\end{abstract}

Kata kunci: komunikasi organisasi, loyalitas karyawan, iklim organisasi, produktifitas kinerja

Abstract

This study aims to determine and analyze the effect of organizational communication patterns, employee loyalty and organizational climate on organizational work productivity at Al-Munawwarah Islamic Boarding School. This type of research is quantitative research, using survey methods. The survey method is a method in a study in which information is collected from several samples by presenting research results in the form of numbers or statistics. This research uses Structural Equation Model (SEM) with data analysis tool for hypothesis testing is Partial Least Square (PLS) using SmartPLS ver 2.0 M3 software application. PLS is a powerful analytical method because it can be applied to all data scales, does not require many assumptions and the sample size is not too large. Al-Munawwara.

Keywords: organizational communication, employee loyalty, organizational climate, productivity performance

\section{PENDAHULUAN}

Pendidikan merupakan aspek penting bagi perkembangan sumber daya manusia. Sebab pendidikan merupakan wahana atau salah satu instrumen yang digunakan bukan saja untuk membebaskan manusia dari keterbelakangan, melainkan juga dari kebodohan dan kemiskinan. Pendidikan diyakini mampu menanamkan kapasitas baru bagi semua orang untuk mempelajari pengetahuan dan keterampilan baru sehingga dapat diperoleh manusia produktif. Di sisi lain, pendidikan dipercayai sebagai wahana perluasan akses dan mobilitas sosial dalam masyarakat baik secara horizontal maupun vertikal.

Regulasi terkait system pendidikan nasional yang ada di di Indonesia dijelaskan bahwa ada tiga jalur pendidikan, yaitu; jalur pendidikan formal, nonformal dan informal. Hal ini terkandung dalam Undang-Undang Nomor 20 Tahun 2003 tentang Sistem Pendidikan Nasional menjadi 3 jalur, yaitu jalur pendidikan formal, nonformal dan informal. Pengertian masing-masing jalur tersebut seperti yang 
dijelaskan dalam pasal 1 ayat 11, 12 dan 13 Undang-undang Nomor 20 Tahun 2003 sebagai berikut: Pendidikan formal adalah jalur pendidikan yang terstruktur dan berjenjang yang terdiri atas pendidikan dasar, pendidikan menengah, dan pendidikan tinggi. Pendidikan nonformal adalah jalur pendidikan di luar pendidikan formal yang dapat dilaksanakan secara terstruktur dan berjenjan. Sedangkan pendidikan informal adalah jalur pendidikan keluarga dan lingkungan.

Sangat mudah dipahami bahwa kemajuan suatu bangsa sangat ditentukan oleh kualitas sumber daya manusia. Dan kualitas sumber daya manusia bergantung pada kualitas pendidikan. Peran pendidikan sangat penting untuk menciptakan masyarakat yang cerdas, damai, terbuka, dan demokratis. Oleh karena itu, pembaharuan pendidikan harus selalu dilakukan untuk meningkatkan kualitas pendidikan suatu bangsa. Kemajuan Bangsa Indonesia hanya dapat dicapai melalui penataan pendidikan yang baik. Berbagai upaya peningkatan mutu pendidikan diharapkan dapat menaikan harkat dan martabat manusia Indonesia.

Pondok Pesantren merupakan salah satu Lembaga Pendidikan Islam non formal dan formal yang berada di bawah naungan suatu Yayasan pada umumnya. Sebagai lembaga pendidikan non formal, Pondok Pesantren memiliki kurikulum pendidikan kekhususan yang berbeda dengan kurikulum lembaga pendidikan lainnya. Kurikulum kekhususan merupakan salah satu yang menjadi identitas pada sebuah pondok pesantren. Namun sebagai lembaga formal, Pondok Pesantren juga menjalankan kurikulum yang dikeluarkan oleh Pemerintah secara resmi. Artinya untuk mencapai visi dan misinya Pondok Pesantren memadukan kurikulum kekhasannya dengan kurikulum resmi dari pemerintah

Maka salah satu indicator dari ketercapaian tujuan organisasi adalah bagaimana tinggi atau rendahnya produktifitas organisasi tersebut. Oleh karena itu, Pondok Pesantren sebagai lembaga Pendidikan Islam dalam mengelola dan menyelenggarakan pendidikan formal dan nonformal haruslah didukung oleh sumber daya manusia yang berkualitas, sumber daya manusia yang kompeten dan kompetitif.

Sumber daya manusia pada sebuah organisasi merupakan asset yang harus dikelola dengan baik. Karena SDM adalah unsur terpenting dan salah satu factor penentu dalam usaha mencapai dan meningkatkan produktifitas kerja organisasi untuk mencapai tujuannya. Produktivitas kerja selalu diarahkan pada bagaimana melakukan atau memanfaatkan sesuatu agar mencerminkan prinsip efektivitas dan efisiensi. Dikatakan efisien manakala apa yang dilakukan mempertimbangkan aspek biaya, sarana prasarana sumber daya (manusia dan material), dan waktu sehemat mungkin. Sedangkan sesuatu dikatakan efektif bila pemanfaatan berbagai aspek tersebut benar-benar tepat sasaran atau tujuan yang diinginkan

Hasil penelitian Ida Ayu Brahmasari juga memperkuat pendapat Ivancevich, Konopaske dan Matteson, (2005) serta Kinicki dan Kreitner (2007). Yaitunya, komunikasi membantu anggota organisasi untuk mencapai baik tujuan individu maupun organisasi, mengimplementasikan dan merespon perubahan organisasi, mengkoordinasikan berbagai aktivitas, dan berkaitan secara virtual dengan semua perilaku yang relevan dengan organisasi. Jika komunikasi organisasi kurang efektif maka organisasi juga tidak seefektif yang seharusnya. Sehingga kurangnya efektifitas organisasi akan dapat menghambat produktifitas organisasi yang diharapkan.

Vannecia Marchelle Soegandhi dkk dalam sebuah jurnal yang berjudul; "Pengaruh Kepuasan Kerja dan Loyalitas Kerja terhadap Organizational Citizenship Behavior pada Karyawan PT.Surya Timur Sakti Jatim" menyatakan bahwa kepuasan kerja dan loyalitas kerja secara simultan berpengaruh terhadap organizational citizenship behavior, hal ini tentunya menguntungkan perusahaan karena karyawan telah memilki produktifitas yang baik.

Penelitian tersebut menyimpulkan bahwa kepuasan kerja dan loyalitas kerja ternyata mempunyai pengaruh yang positif dan signifikan terhadap organizational citizenship behavior karyawan. Hal ini dapat 
diartikan bahwa tanpa Kepuasan Kerja dan Loyalitas dalam diri karyawan maka organizational citizenship behavior akan menurun.

Alasannya adalah karyawan yang merasa tidak puas dalam bekerja cenderung memiliki persepsi negatif dan merasa tidak memiliki kontribusi terhadap perusahaan. Akibatnya hal ini dapat meningkatkan stress dan emosi dalam diri karyawan. Sehingga hasil kerjanya akan tidak maksimal atau bahkan buruk. Karyawan yang tidak puas terhadap pekerjaannya kecil kemungkinan akan mau memberikan extra-role terhadap perusahaan. Sedangkan tanpa loyalitas karyawan salah satu dampaknya akan meningkatkan turnover yang malah akan merugikan perusahaan dalam hal waktu dan biaya karena harus melakukan training lagi kepada karyawan baru dan sebagainya.

Penelitian M. Soleh Lubis (2015), yang berjudul, "Pengaruh Iklim Organisasi dan Komitmen Organisasi terhadap Pembentukan Organizational Citizenship Behavior (OCB) Karyawan dalam rangka Peningkatan Kinerja", juga menjelaskan iklim organisasi berpengaruh positif dan signifikan terhadap Organizational Citizenship Behavior yang mempengaruhi peningkatan kinerja. Sementara menurut Shcermerhorn, (1991), kinerja juga dapat diartikan sebagai hasil kerja secara kualitas dan kuantitas pencapaian tugas-tugas baik yang dilakukan oleh individu, kelompok maupun perusahaan.

Terkait masalah peningkatan produktifitas pada suatu organisasi, Sukarman Kamuli (2012) dalam penelitiannya yang berjudul, "Pengaruh Iklim Organisasi terhadap Produktivitas Kerja Pegawai Di Sekretariat Daerah kota Gorontalo" juga menjelaskan bahwa secara simultan iklim organisasi berpengaruh terhadap produktivitas kerja pegawai di secretariat daerah Kota Gorontalo sebesar 35,14\%.

Secara teoritik banyak faktor yang turut mempengaruhi produktivitas kerja pegawai dalam suatu organisasi, antara lain: kualitas sumber daya manusia, sarana dan prasarana yang tersedia, dan lingkungan organisasi baik yang sifatnya eksternal maupun lingkungan organisasi yang sifatnya internal. Tetapi pengendali utama tetap berada pada unsur manusia ( Kamuli, Sukarman: 2012).

Pondok Pesantren di Provinsi Riau yang terdata oleh Kantor Wilayah Kementerian Agama Provinsi Riau berjumlah 183 Pondok Pesantren yang tersebar di seluruh Kota dan kabupaten yang ada, dengan total seluruh siswa/santrinya hampir mencapai 35.000 orang dan tenaga pendidiknya berjumlah lebih dari 3.600 orang.

Tabel 1.1. Jumlah Pondok Pesantren di Provinsi Riau beserta jumlah santri dan tenaga pendidiknya.

\begin{tabular}{llccccc}
\multirow{2}{*}{ No } & Kabupaten/Kota & Pesantren & \multicolumn{2}{c}{ Murid } & \multicolumn{2}{c}{ Guru } \\
\cline { 3 - 7 } & & $\begin{array}{c}\text { Laki- } \\
\text { laki }\end{array}$ & $\begin{array}{c}\text { Peremp } \\
\text { uan }\end{array}$ & $\begin{array}{c}\text { Laki- } \\
\text { laki }\end{array}$ & $\begin{array}{c}\text { Perem } \\
\text { puan }\end{array}$ \\
\hline 1. & Kuantan Singingi & 5 & 305 & 316 & 68 & 76 \\
\hline 2. & Indragiri Hulu & 10 & 981 & 1.337 & 130 & 154 \\
\hline 3. & Indragiri Hilir & 31 & 3.384 & 3.619 & 190 & 76 \\
\hline 4. & Pelalawan & 10 & 1.095 & 938 & 150 & 115 \\
\hline 5. & Siak & 16 & 1.109 & 1.115 & 166 & 107 \\
\hline 6. & Kampar & 32 & 3.422 & 3.488 & 447 & 526 \\
\hline 7. & Rokan Hulu & 14 & 780 & 604 & 153 & 103 \\
\hline 8. & Bengkalis & 16 & 959 & 851 & 108 & 91 \\
\hline 9. & Rokan Hilir & 20 & 1.017 & 985 & 120 & 50 \\
\hline 10. & Kepulauan Meranti & 12 & 372 & 381 & 54 & 30 \\
\hline 11. & Pekanbaru & 12 & 2.490 & 3.035 & 384 & 239 \\
\hline 12. & Dumai & 5 & 211 & 154 & 45 & 32 \\
\hline
\end{tabular}




\begin{tabular}{crrrrr}
\hline Jumlah/Total & 183 & 16.125 & 16.823 & 2.015 & 1.599 \\
\hline Sumber: Kanwil Kementrian Agama Provinsi Riau (Tahun 2017)
\end{tabular}

Pondok Pesantren (Ponpes) Al- Munawwarah, adalah salah satu Pondok Pesantren yang ada di Kota Pekanbaru. Ponpes Al-Munawwarah berdiri pada Bulan Juni 1986, dan merupakan Pondok Pesantren tertua yang ada di Kota Pekanbaru.

Pondok Pesantren Al-Munawwarah memiliki Visi yaitu; "Terwujudnya lembaga yang menghasilkan lulusan yang berilmu, beriman, bertaqwa, berakhlak mulya, terampil dan mandiri". Dan mengemban Misi sebagai berikut; (1). Mencetak manusia yang beriman dan bertaqwa kepada Allah SWT. (2). Mencetak manusia yang menguasai ilmu pengetahuan dan teknologi tepat guna. (3). Mencetak manusia sebagai pemimpin yang jujur dan bertanggung jawab. (4). Mencetak manusia yang melaksanakan amar ma'ruf dan nahi mungkar. (5). Mencetak manusia yang menjadi contoh dan berakhlak mulya.

Maka untuk mencapai visi dan misinya Ponpes Al-Munawwarah menjalankan Program pendidikan formal dan non formal. Program pendidikan formal mempelajari pelajaran-pelajaran yang disusun dalam kurikulum resmi pemerintah atau kurikulum nasional. Ditambah dengan program pendidikan yang menjalankan kurikulum khas atau khusus. Yaitu kurikulum pondok yang mempelajari atau mengkaji Kitab-kitab klasik yang lebih dikenal dengan istilah Kitab Kuning/ Kitab Arab Gundul.

Ponpes Al-Munawwarah juga melaksanakan pendidikan nonformal di bidang pembinaan akhlak, pembinaan minat dan bakat dan pembinaan keagamaan. Pembinaan minat dan bakat dalam bentuk kegiatan ekstrakurikuler, (terdiri dari; pencak silat, Tahfizd Qur'an, Seni Qiraah, Hadroh, Nasyid, dll). Sedangkan pembinaan keagaamaan seperti sholat fardhu berjamaah, sholat dhuha berjamaah, kegiatan membaca Al-Qur'an, dan lain-lain. Selain itu juga terdapat kegiatan Muhadharah, yaitu kegiatan wajib bagi seluruh santri untuk melatih dan membiasakan santri menyampaikan wawasannya dalam forum terbuka. Pembinaan lainnya adalah pembinaan kemandirian dan keterampilan, serta pembinaan kegiatankegiatan ilmiah bidang kajian umum dan ilmiah bidang kajian agama seperti kegiatan Muzakarah dan Mutholaah.

Sejak berdirinya, Ponpes Al-Munawwarah tetap konsisten dengan identitasnya, yaitu menjadikan pelajaran kitab kuning sebagai "Tajul Ma'had" atau Mahkota Pondok. Sehingga dalam perjalanannya untuk tetap pada prinsip pendirian serta cita-cita pendirinya, Pondok Pesantren ini senantiasa mengalami transformasi pada setiap kurun waktu tertentu demi terus memperbaiki strategi untuk mencapai tujuan lembaga.

Namun pada sepuluh tahun belakangan ini secara umum, dan tepatnya dalam enam tahun ini Ponpes Al-Munawwarah telah mengalami banyak kemajuan baik secara kuantitas maupun kualitasnya. Secara kuantitas, jumlah santrinya terus bertambah dari tahun ke tahun. Jumlah santri yang meningkat setiap tahun diiringi dengan meningkatnya jumlah tenaga pendidik, pengasuh, dan karyawan lainnya. Hal tersebut dapat dilihat pada table berikut:

Tabel 1.2. Santri dan Tenaga Pendidik/Pengasuh Pondok Pesantren Al- Munawwarah

\begin{tabular}{ccccc}
\hline NO & TAHUN & $\begin{array}{c}\text { JUMLAH } \\
\text { SANTRI }\end{array}$ & $\begin{array}{c}\text { JUMLAH } \\
\text { PENDIDIK/PENGASUH }\end{array}$ & $\begin{array}{c}\text { TENAGA } \\
\text { KHUSUS* }\end{array}$ \\
\hline 1 & 2015 & 780 Orang & 70 Orang & 5 \\
\hline 2 & 2016 & 789 Orang & 75 Orang & 7 \\
\hline 3 & 2017 & 823 Orang & 75 Orang & 7 \\
\hline 4 & 2018 & 846 Orang & 81 Orang & 9 \\
\hline
\end{tabular}




\section{$52019 \quad 936$ Orang $\quad 86$ Orang 15 \\ Keterangan *: Terdiri dari Bidan dan Dokter Klinik, scuerity, driver, tukang masak, dan kebersihan.}

Prestasi dan kebanggaan baru bagi Pondok Pesantren Al-Munawwarah adalah diterbitkannya SK dari Kementrian Agama R.I Tahun 2019 tentang Ma'had 'Aly. Ma'had 'Aly adalah Perguruan Tinggi berbasis kitab kuning yang pertama ada di Provinsi Riau dan sudah mulai menjalankan pembelajarannya pada Bulan Agustus Tahun Pelajaran 2020-2021.

Dengan demikian melihat keadaan perkembangannya saat ini dapat dikatakan bahwa Pondok Pesantren Al-Munawwarah telah mampu membangun rantai linearitas keilmuan berbasis Kitab Kuning. Hal ini dibuktikan dengan adanya jenjang pendidikan tingkat SLTP, SLTA dan Perguruan Tinggi yang memuat pembelajaran Kitab Kuning secara terstruktur.

Maka berdasarkan teori-teori tentang pola komunikasi, loyalitas karyawan dan iklim organisasi yang mempengaruhi produktifitas kerja organisasi serta berdasarkan fenomena keadaan Pondok Pesantren Al-Munawwarah di atas, penulis tertarik untuk melihat dan meneliti lebih lanjut keadaan Pondok Pesantren Al-Munawwarah dengan penelitian, Pengaruh Pola Komunikasi Organisasi, Loyalitas Karyawan Dan Iklim Organisasi Terhadap Produktivitas Kerja Organisasi Pada Pondok Pesantren AlMunawwarah Di Kota Pekanbaru.

\section{METODE}

Jenis penelitian ini adalah penelitian kuantitatif, dengan menggunakan metode survey. Metode survey merupakan metode dalam sebuah penelitian yang informasinya dikumpulkaan dari beberapa sampel dengan penyajian hasil penelitian dalam bentuk angka-angka atau statistic. Maka dengan menggunakan metode ini dimaksudkan untuk mengetahui lebih mendalam pengaruh pola komunikasi organisasi, loyalitas karyawan dan iklim organisasi terhadap produktivitas kerja organisasi pada Pondok Pesantren Al-Munawwarah. Sehingga pada akhir penelitian dapat diketahui gambaran berapa nilai masing-masing variable serta pengaruh independen terhadap dependen.

Adapun yang teknik sampling yang digunakan dalam penelitian ini adalah metode sensus ( sampling jenuh), yaitu teknik penentuan sampel bila semua anggota populasi digunakan sebagai sampel. Sampel sensus ini digunakan apabila populasinya kurang dari 100 orang. Maka yang mejadi sampel dalam penelitian ini adalah seluruh tenaga pendidik dan kependidikan, serta pengasuh yang berjumlah 86 orang.

Penelitian ini menggunakan Structural Equation Model (SEM) dengan alat analisis data untuk pengujian hipotesis adalah Partial Least Square (PLS) menggunakan aplikasi perangkat lunak SmartPLS ver 2.0 M3. PLS merupakan metode analisis yang powerful karena dapat diterapkan pada semua skala data, tidak membutuhkan banyak asumsi dan ukuran sampel tidak terlalu besar, (Jaya: 2008). Adapun variable kunci yang menjadi perhatian dalam SEM adalah variable laten, atau konstruk laten. SEM memiliki dua jenis variable laten, yaitu eksogen dan endogen. Variabel eksogen dapat juga dikatakan sebagai variable bebas. Sedangkan variable endogen biasa disebut sebagai variable terikat. 


\section{HASIL DAN PEMBAHASAN}

\section{Pengujian Signifikansi dan Pengujian Hipotesis}

Dalam PLS pengujian secara statistik setiap hubungan yang dihipotesiskan dilakukan dengan menggunakan simulasi. Dalam hal ini dilakukan metode bootstrap terhadap sampel. Pengujian dengan bootstrap juga dimaksudkan untuk meminimalkan masalah ketidaknormalan data penelitian. Parameter signifikansi yang diestimasi memberikan informasi yang sangat berguna mengenai hubungan antara variabel-variabel penelitian. Hasil pengujian dengan bootstrapping dari analisis PLS dapat dilihat pada output result for inner weight yang disajikan pada gambar model struktural.

\section{Gambar 3.1. Pengujian Bootstrapping dari Analisis PLS}

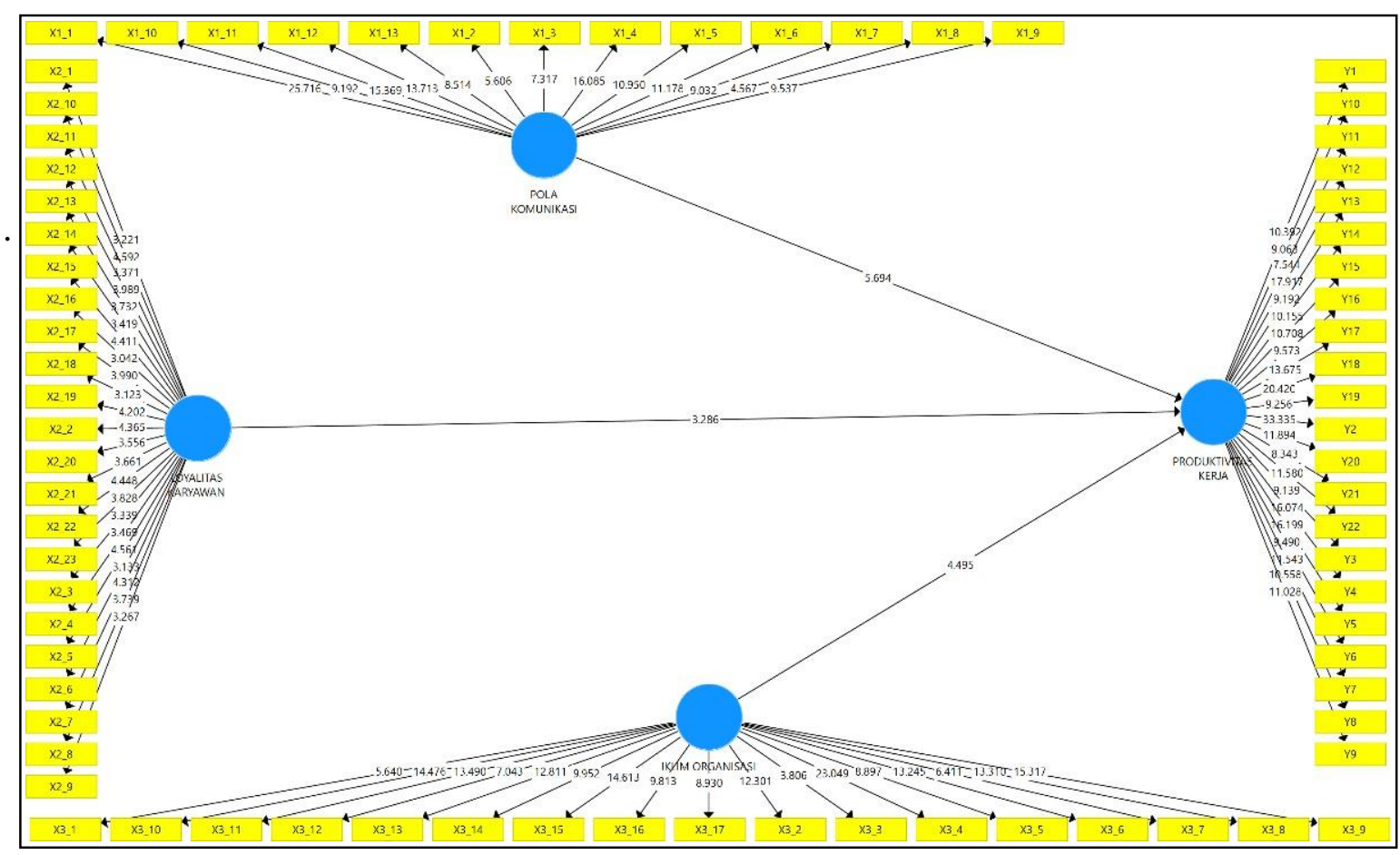

Berdasarkan gambar di atas berikut akan dijelaskan pengujian masing-masing hipotesis.Model struktural (inner model) merupkan model struktural untuk memprediksi hubungan kausalitas antar variabel laten (Latan, Gozali, 2012:77). Untuk memprediksi adanya hubungan kausalitas dalam SEMPLS dengan menggunakan SmartPLS 3.0 M3 sebagai berikut :

Tabel 5.5. Result For Inner Weights

\begin{tabular}{|c|c|c|c|c|c|}
\hline Variabel & $\begin{array}{c}\text { Original } \\
\text { Sample } \\
(\mathrm{O})\end{array}$ & $\begin{array}{c}\text { Sample } \\
\text { Mean } \\
(\mathrm{M})\end{array}$ & $\begin{array}{c}\text { Standard } \\
\text { Deviation } \\
(\text { STDEV })\end{array}$ & $\begin{array}{c}\text { T Statistics } \\
(\mid \mathrm{O} / \mathrm{STDEV})\end{array}$ & $\begin{array}{c}\mathrm{P} \\
\text { Values }\end{array}$ \\
\hline $\begin{array}{c}\text { POLA } \\
\text { KOMUNIKASI -> } \\
\begin{array}{c}\text { PRODUKTIVITAS } \\
\text { KERJA }\end{array}\end{array}$ & 0.465 & 0.454 & 0.082 & 5.694 & 0.000 \\
\hline
\end{tabular}




\begin{tabular}{|c|c|c|c|c|c|}
\hline $\begin{array}{c}\text { LOYALITAS } \\
\text { KARYAWAN -> } \\
\text { PRODUKTIVITAS } \\
\text { KERJA }\end{array}$ & 0.260 & 0.268 & 0.079 & 3.286 & 0.001 \\
\hline $\begin{array}{c}\text { IKLIM } \\
\text { ORGANISASI -> } \\
\text { PRODUKTIVITAS } \\
\text { KERJA }\end{array}$ & 0.400 & 0.403 & 0.089 & 4.495 & 0.000 \\
\hline
\end{tabular}

Sumber : Olahan Data SmartPLS

Berdasarkan hasil analisis yang dapat dilihat pada tabel diatas menunjukan nilai koefisien pola komunikasi -> produktivitas kerja sebesar 0.465 dengan nilai t hitung sebesar 5.694. Nilai tersebut lebih besar dari t tabel 1.989. Hasil ini membuktikan pengaruh signifikan pola komunikasi $\rightarrow$ produktivitas kerja, sehingga h1 diterima

Berdasarkan hasil analisis yang dapat dilihat pada tabel diatas menunjukan nilai koefisien loyalitas karyawan -> produktivitas kerja sebesar 0.260 dengan nilai t hitung sebesar 3.286. Nilai tersebut lebih besar dari t tabel 1.989. Hasil ini membuktikan pengaruh signifikan loyalitas karyawan -> produktivitas kerja, sehingga h2 diterima.

Berdasarkan hasil analisis yang dapat dilihat pada tabel diatas menunjukan nilai koefisien iklim organisasi -> produktivitas kerja sebesar 0.400 dengan nilai t hitung sebesar 4.495. Nilai tersebut lebih besar dari t tabel 1.989. Hasil ini membuktikan pengaruh signifikan iklim organisasi -> produktivitas kerja, sehingga h3 diterima.

\section{Pembahasan}

\section{Pengaruh Pola Komunikasi Organisasi terhadap Produktivitas Kerja}

Berdasarkan hasil analisis yang dapat dilihat pada tabel 5.5 diatas menunjukan nilai koefisien jalur pengaruh Pola Komunikasi Organisasi terhadap Produktivitas Kerja 0.465 dengan nilai t hitung sebesar 5.694. Nilai tersebut lebih besar dari t tabel 1.989. Karena t hitung $5.694>\mathrm{t}$ table 1,986 maka disimpulkan bahwa Pola Komunikasi berpengaruh secara signifikan terhadap Produktivitas Kerja pada organisasi.

Komunikasi merupakan alat yang sangat penting untuk menyampaikan dan menerima informasi kepada atau pihak lain. Sebagaimana disampaikan oleh Rois (2017) tujuan akhir dari efektifitas sebuah system komunikasi di dalam organisasi adalah bagaimana system komunikasi itu dapat membentuk perilaku individu dalam organisasi.

Pola komunikasi organisasi terdiri dari empat pola, yaitu; komunikasi ke bawah, komunikasi ke atas, komunikasi horizontal dan komunikasi diagonal. Komunikasi ke bawah menggambarkan system informasi atau pesan dari atasan kepada bawahannya. Informasi atau pesan yang disampaikan oleh pimpinan/atasan haruslah jelas dan terukur. Hal ini dimaksud agar anggota organisasi dapat dengan mudah memahami tugas yang akan dilakukan. Sehingga tujuan pekerjaan dapat tercapai dengan baik. Pada penelitian ini, pola komunikasi ke bawah ditunjukkan oleh X1-1, X1-2 dan X1-3 dalam pernyataan yang terdapat pada Kuisioner Penelitian.

Komunikasi ke atas, bagaimana system komunikasi yang dibangun oleh atasan/pimpinan agar bawahannya dapat menyampaikan informasi atau pesan kepadanya. Untuk memperoleh system informasi yang baik dengan tujuan kemajuan organisasi, pimpinan/atasan akan secara terbuka dan bijak menerima 
pesan dari bawahannya. Pernyataan yang mewakili bentuk komunikasi ke atas terdapat pada X1-4, X1-5 dan X1-6 pada kuisioner penelitian

Untuk pola komunikasi horizontal cenderung diciptakan sendiri oleh anggota organisasi atau sesama rekan kerja yang berada dalam satu unit kerja. Baik itu bahasa yang digunakan maupun cara berkomunikasinya. Untuk itu agar dapat bekerja dengan baik dan dapat memberikan hasil yang baik, anggota organisasi harus mampu berkomunikasi dengan baik pula dengan sesama rekan kerjanya. Pernyataan yang mewakili bentuk komunikasi ke atas terdapat pada X1-7, X1-8 dan X1-9 pada kuisioner penelitian.

Pola komunikasi diagonal boleh dikatakan sama dengan pola komunikasi horizontal. Perbedaannya terletak pada unit kerja. Jika komunikasi horizontal terjadi pada dalam satu unit kerja, maka komunikasi diagonal terjadi antara beberapa unit kerja yang ada dalam satu organisasi. Di Pondok Pesantren AlMunawwarah terdapat beberapa unit kerja. Yaitu unit kerja lingkungan non formal dan informal serta unit kerja formal atau lingkup madarasah. Pada unit kerja nonformal dan informal terdapat unit kerja lingkungan putrid an lingkungan putra. Sedangkan unit kerja di madrasah terdapat empat madrasah, (MTs, MA, PDF Wustho dan PDF Ulya). Agar terciptanya system kerja yang baik dan terarah, maka perlu dibangun system komunikasi diagonal yang baik pula. Untuk pola komunikasi ini diwakili oleh X1-10, X1-11 dan X1-12 dalam pernyataan pada kuisioner penelitian.

Maka sesuai dengan hasil pengujian dengan bootstrapping dari analisis PLS dapat dilihat pada output result for inner weight pada tabel 5.5. membuktikan bahwa Pola Komunikasi Organisasi berpengaruh secara signifikan terhadap Produktivita kerja di Pondok Pesantren Al-Munawwarah.

Artinya, bahwa empat pola komunikasi organisasi yang ada di Pondok Pesantren Al-Munawwarah memberikan pengaruh terhadap produktivitas kerja. Hal ini sesuai dengan pendapat Gibson dkk dalam Rois Arifin (2017), yang menjelaskan bahwa empat arah komunikasi tersebut menentukan kerangka kerja dalam organisasi. Jika masing-masing arah dapat dilihat dan diteliti dengan baik, memungkinkan manajer dapat menyadari dengan lebih baik adanya rintangan yang menghalangi komunikasi organisasi yang efektif serta memahamilangkah-langkah untuk mengatasi rintangan tersebut.

\section{Pengaruh Loyalitas Karyawan terhadap Produktivitas Kerja}

Berdasarkan hasil analisis yang dapat dilihat pada tabel 5.5. diatas menunjukan nilai koefisien LOYALITAS KARYAWAN -> PRODUKTIVITAS KERJA sebesar 0.260 dengan nilai t hitung sebesar 3.286. Nilai tersebut lebih besar dari $t$ tabel 1.989. Hasil ini membuktikan pengaruh signifikan LOYALITAS KARYAWAN -> PRODUKTIVITAS KERJA, sehingga H2 diterima.

Loyalitas adalah bentuk kesetiaan karyawan terhadap organisasi tempatnya bekerja dengan memberikan yang terbaik yang dapat dilakukannya. Menurut Hasibuan (2001) dalam Vannecia dkk, loyalitas merupakan salah satu unsur yang digunakan dalam penilaian karyawan yang mencakup kesetiaan terhadap pekerjaannya, jabatannya dan organisasi.

Penelitian ini mengemukakan bagaimana loyalitas karyawan (tenaga pendidik) yang dapat memberikan pengaruh terhadap produktivitas kerja di pondok Pesantren Al-Munawwarah Kota Pekanbaru. Maka aspek-aspek yang diteliti adalah bagaimana keadaan karyawan (tenaga pendidik) yang taat kepada aturan, bertanggung jawab, memiliki kemauan untuk bekerjasama, adanya rasa memiliki, hubungan antar pribadi, dan kesukaan terhadap pekerjaan.

Karyawan yang taat pada aturan adalah karyawan yang memahami bahwa aturan yang dibuat oleh lembaga/organisasi adalah untuk kebaikan dan kemajuan organisasi. Selain itu karyawan juga menyadari bahwa salah satu tujuan aturan adalah menjadikannya lebih tertib dan disiplin. Maka dengan demikian karyawan akan dengan lapang hati dalam menjalankan setiap tugas yang dibebankan kepadanya. Hal ini 
tentu akan memberikan dampak positif terhadap hasil kerja karyawan tersebut. Aspek taat kepada aturan ini terdapat pada Variabel X2-1, X2- 2 dan X2-3 dalam pernyataan pada kuisioner penelitian.

Menunjukkan sikap bertanggung jawab merupakan salah satu bentuk loyalitas karyawan terhadap organisasinya. Maka karyawan yang bertanggung jawab memahami bahwa setiap pekerjaan/tugas yang diembannya memiliki konsekuensi yang harus diterimanya. Selanjutnya dengan keadaan tersebut karyawan akan berusaha dengan baik dan maksimal dalam menjalankan setiap tugas. Dan dengan sikap tanggung jawab yang dimiliki oleh karyawan, karyawan akan siap menerima pembinaan dari organisasinya. Aspek sikap tanggung jawab diwakili oleh X2-4, X2-5 dan X2-6 dalam pernyataan pada kuisioner.

Karyawan yang loyal juga memiliki sikap kemauan untuk bekerja sama. Hal ini ditunjukkaan pada indicator; karyawan memahami memahami bahwa dengan bekerjasama dapat meringankan pekerjaan dalam rangka mencapai hasil yang baik. Karyawan juga menyadari bahwa bekerja secara individu tidak akan mungkin mampu mencapai hasil kerja yang baik. Sehingga karyawan yang memiliki kemauan untuk bekerjasama akan mampu bekerja secara TIM dengan siapa pun rekan kerjanya di dalam organisasi tersebut. Aspek sikap ini tercantum dalam pernyataan pada variable X2-7, X2-8 dan X2-9 pada kuisioner penelitian.

Sikap rasa memiliki terhadap organisasi juga menjadi salah satu bentuk sikap loyalitas pada karyawan. Adapun yang menjadi indicator pada sikap rasa memiliki ini adalah; pertama; karyawan merasa lembaga/organisasi tempatnya bekerja harus dijaga nama baiknya. Kedua; karyawan merasa bahwa organisasi tempatnya bertugas bukan sekedar untuk mencukupi kebutuhan finansialnya. Ketiga; karyawan merasa harus melindungi lembaga tempatnya bertugas dari ancaman berbagai hal. Keempat; Karyawan merasa harus memberikan yang terbaik dari setiap usahanya untuk memajukan organisasi. Kelima; karyawan merasa bahwa dirinya adalah bahagian dari organisasi.

Karyawan yang loyal, merasa memiliki organisasi tempatnya bertugas. Sehingga menjadikan organisasi tersebut sebagai bagian dari dirinya yang harus dijaga kehormatannya, dilindungi serta dibangun menjadi lebih baik dan maju. Lima indicator tersebut terdapat pada variable X2-10, X2-11, X212, X2-13 dan X2-14 dalam pernyataan pada kuisioner.

Karyawan yang loyal juga memiliki hubungan antar pribadi yang baik dengan sesama anggota organisasi dan memiliki hubungan social yang baik dengan rekan-rekan kerjanya. Memiliki hubungan yang baik, dapat memicu perasaan positif. Seperti, ketika rekan kerja meraih prestasi dan penghargaan maka karyawan akan merasa termotivasi untuk menjadi lebih baik lagi. Selain itu juga dapat memicu perasaan menjadi anggota keluarga dan merasa diperhatikan oleh organisasi. Deskripsi ini dapat dilihat pada variable X2-15, X2-16, X2-17, X2-18 dan X2-19 dalam pernyataan pada kuisinoer.

Indicator terakhir adalah kesukaan terhadap pekerjaan. Karyawan yang loyal akan menunjukkan sikap kesukaan terhadap pekerjaannya. Indikasinya adalah berusaha dengan maksimal dalam menjalankan tugasnya, menerima dengan lapang hati kebijakan kompensasi yang diterimanya, tidak menuntut kompensasi lain di luar kebijakan lembaga atau menuntut kompensasi ekstra saat melakukan pekerjaan di luar jam dinas dalam rangka menyelesaikan pekerjaanya tepat waktu. Hal ini dapat dilihat pada variable X2-20, X2-21, X2-22 dan X2- 23 dalam pernyataan pada kuisioner penelitian.

Sesuai dengan hasil pengujian dengan bootstrapping dari analisis PLS dapat dilihat pada output result for inner weight pada tabel 5.5. membuktikan bahwa loyalitas karyawan berpengaruh secara signifikan terhadap Produktivita kerja di Pondok Pesantren Al-Munawwarah.

Artinya, tenaga pendidik di Pondok Pesantren Al-Munawwarah telah menunjukkan sikap loyal terhadap organisasinya. Sikap loyal ini memberikan pengaruh yang baik dalam melakukan pekerjaan. Sehingga dapat meningkatkan produktivitas kerja. Hal ini sesuai dengan pendapat Gauzali (2005) yang mengatakan bahwa salah satu manfaat loyalitas karyawan adalah dapat meningkatkan produktivitas kerja. 


\section{Pengaruh Iklim Organisasi terhadap Produktivitas Kerja}

Berdasarkan hasil analisis yang dapat dilihat pada tabel 5.5. diatas menunjukan nilai koefisien iklim organisasi -> produktivitas kerja sebesar 0.400 dengan nilai t hitung sebesar 4.495. Nilai tersebut lebih besar dari t tabel 1.989. Hasil ini membuktikan pengaruh signifikan iklim organisasi -> produktivitas kerja, sehingga $\mathbf{H 3}$ diterima.

Iklim organisasi adalah keadaan internal organisasi yang berkualitas yang terjadi secara terus menerus yang dapat mempengaruhi perilaku anggota organisasi. Tagiurin dan Litwin (1968) dalam Etty Susanti (2012), menyampaikan bahwa Iklim Organisasi adalah kualitas internal organisasi yang bertahan cukup lama yang dialami oleh anggota organisasi yang mempengaruhi perilaku mereka yang dapat digambarkan sebagai cerminan nilai-nilai dari seperangkat ciri khas organisasi tersebut.

Tagiurin dan Litwin lebih lanjut menjelaskan, bahwa kualitas internal organisasi yang dimaksud bukan kondisi subjektif yang sama bagi semua karyawan, melainkan kondisi yang sudah diproses melalui persepsi sepanjang pengalaman subjektif dan kemudian pengalaman subjektif karyawan berpengaruh pada perilaku bagaimana ia bekerja dan bertindak di dalam organisasi.

Penelitian ini memaparkan bagaimana keadaan iklim organisasi di Pondok Pesantren AlMunawwarah yang dirasakan oleh tenaga pendidiknya sehingga memberikan pengaruh terhadap produktivitas kerja. Adapun dimensi-dimensi iklim organisasi adalah; strukut organisasi, standar, tanggung jawab, pengakuan, dukungan dan komitmen.

Struktur organisasi, merefleksikan perasaan anggota organisasi mengenai peran dan tanggung jawab mereka. Indikasinya adalah bahwa anggota organisasi memahami posisi dan tugasnya sehingga mampu bertindak sesuai dengan kewenangannya. Selain itu juga terdapat keadaan organisasi yang memiliki tupoksi yang jelas agar anggotanya dapat bekerja dengan terarah untuk mencapai hasil yang baik. Keadaan ini dapat dilihat pada X3-1, X3-2, X3-3, X3-4 dan X3-5 dalam pernyataan pada kuisioner penelitian.

Standar, mengukur perasaan tekanan untuk memperkirakan kinerja dan derajat kebanggan yang dimiliki oleh karyawan dalam melakukan pekerjaannya dengan baik. Adapun indikasinya adalah, organisasi memiliki daya ukur kinerja yang jelas, lingkungan organisasi yang memberi motivasi serta memberikan kebanggan pada prestasi kerja anggotanya. Keadaan ini dapat dilihat pada X3-6,X3- 7 dan X3-8 dalam pernyataan pada kuisioner penelitian.

Tanggung jawab, merefleksikan perasaan karyawan bahwa mereka menjadi "pimpinan diri sendiri" dan tidak pernah meminta pendapat kepada orang lain mengenai keputusannya. Indikasinya adalah bahwa anggota organisasi menunjukkan sikap bertanggung jawab dan mampu mengambil keputusan atas

pekerjaan yang dilakukan. Keadaan ini dapat dilihat pada X3-9 dan X3-10 dalam pernyataan pada kuisioner penelitian. Pengakuan, perasaan karyawan setelah diberi imbalan yang layak setelah menyelesaikan pekerjaannya dengan baik. Indikasinya adalah organisasi memberikan apresiasi yang baik atas prestasi anggotanya dan menghargai atas jerih payah yang telah dilakukan oleh anggotanya dalam melaksanakan tugas-tugasnya. Keadaan ini dapat dilihat pada X3-11 dan X3-12 dalam pernyataan pada kuisioner penelitian.

Dukungan, merefleksikan perasaan karyawan mengenai kepercayaan karyawan dan saling mendukung yang berlaku di kelompok kerja. Indikasinya adalah; pertama, anggota organisasi dapat merasakan lingkungan organisasi yang saling memberikan dukungan positif untuk mencapai hasil kerja yang baik. Kedua, organisasi dan anggotanya saling memberikan kepercayaan dan motivasi atas tugastugas yang harus dilaksanakan. Ketiga, organisasi dan anggotanya saling memberikan kepercayaan dan motivasi terhadap TIM yang sudah dibentuk atas tugas-tugas yang harus dilaksanakan. Keadaan ini dapat dilihat pada X3-13, X3-14 dan X3-15 dalam pernyataan pada kuisioner penelitian.

Komitmen, merefleksikan perasaan kebanggan dan komitmen sebagai anggota organisasi. Adapun indikasinya adalah anggota organisasi memiliki komitmen yang baik dalam melaksanakan tugasnya serta 
menunjukkan kebanggan sebagai bahagian dari organisasinya. Keadaan ini dapat dilihat pada X3-16 dan X3- 17 dalam pernyataan pada kuisioner penelitian.

Maka sesuai dengan hasil pengujian dengan bootstrapping dari analisis PLS dapat dilihat pada output result for inner weight pada tabel 5.5. membuktikan bahwa Iklim Organisasi berpengaruh secara signifikan terhadap Produktivita kerja di Pondok Pesantren Al-Munawwarah.

Artinya, bahwa keadaan iklim organisasi di Pondok Pesantren Al- Munawwarah yang dirasakan oleh tenaga pendidiknya memberikan pengaruh positif terhadap produktivitas kerja. Hal ini sesuai dengan pendapat Kamuli (2012) bahwa iklim organisasi merupakan sesuatu yang nyata dirasakan oleh orangorang yang ada di dalam suatu organisasi. Apa yang dirasakan itu dapat mempengaruhi perilakunya yang akhirnya akan menentukan tingkat produktivitas kerja mereka.

\section{KESIMPULAN}

Berdasarkan hasil penelitian dan pembahasan yang telah diuraikan, maka dapat disimpulkan beberapa hal mengenai Penelitian tentang Pengaruh Pola Komunikasi Organisasi, Loyalitas Karyawan dan Iklim Organisasi terhadap Produktivitas Kerja Organisasi di Pondok Pesantren Al-Munawwarah Kota Pekanbaru, sebagai berikut:

1. Pola Komunikasi Organisasi berpengaruh secara signifikan terhadap Produktivitas Kerja Organisasi pada Pondok Pesantren Al-Munawwarah berdasarkan nilai koofisien Pola Komunikasi-> Produktivitas Kerja sebesar 0.465 dengan nilai t hitung sebesar 5.694. Nilai tersebut lebih besar dari t table 1.989. Dengan demikian dapat dikatakan semakin baik Pola Komunikasi organisasi akan semakin baik pula tingkat produktivitas kerja organisasi.

2 Loyalitas Karyawan berpengaruh secara signifikan terhadap Produktivitas Kerja Organisasi pada Pondok Pesantren Al-Munawwarah berdasar nilai koofisien Loyalitas Karyawan-> Produktivitas Kerja sebesar 0.260 dengan nilai t hitung 3.286. Nilai tersebut lebih besar dari t table 1.989. Dengan demikian dapat dikatakan semakin baik Loyalitas karyawan akan semakin baik pula tingkat produktivitas kerja organisasi.

3. Iklim Organisasi berpengaruh secara signifikan terhadap Produktivitas Kerja Organisasi pada Pondok Pesantren Al-Munawwarah berdasar nilai koofisien Iklim Organisasi-> Produktivitas Kerja sebesar 0.400 dengan.nilai t hitung 4.495. Nilai tersebut lebih besar dari nilai t table 1.989. Dengan demikian dapat dikatan bahwa semakin baik Iklim organisasi akan semakin baik pula tingkat produktivitas kerja organisasi.

\section{SARAN}

Berdasar kesimpulan di atas maka penulis dapat memberikan saran sebagai berikut :

1. Untuk meningkatkan produktivitas kerja organisasi, Ponpes Al- Munawwarah dapat memperhatikan dan meningkatkan Pola Komunikasi Organisasi yang baik. Pola komunikasi organisasi yang dimaksud adalah; komunikasi ke bawah, komunikasi ke atas, komunikasi horizontal dan komunikasi diagonal.

2. Untuk meningkatkan produktivitas kerja organisasi, Ponpes Al- Munawwarah dapat memperhatikan dan meningkatkan Loyalitas Karyawan/tenaga pendidik. Dalam hal ini memperhatikan aspek-aspek loyalitas karyawan yang terdiri dari; taat pada aturan, 
bertanggung jawab, memiliki kemauan bekerjasama, adanya rasa memiliki, hubungan antar pribadi dan kesukaan terhadap pekerjaan

3. Untuk meningkatkan produktivitas kerja organisasi, Ponpes Al- Munawwarah dapat memperhatikan dan meningkatkan Iklim Organisasi Adapun dimensi Iklim Organisasi tersebut adalah; suktur organisasi, standar, tanggung jawab, pengakuan, dukungan dan komitmen.

\section{DAFTAR PUSTAKA}

[1] Almigo, Nuzcep. 2004. Hubungan Antara Kepuasan Kerja Dengan Produktivitas Kerja Karyawan. Jurnal PSYCHE Volume 1 No. 1 hal 50 - 59

[2] Davis. K \& Newstrom.2001. Perilaku dalam Organisasi. Jakarta: Erlangga

[3] Dediknas.2003.Undang-Undang R I Nomor 20 Tentang Sistem Pendidikan Nasional. Bandung:Citra Umbara.

[4] Etty Susanti. 2012. Pengaruh Iklim Organisasi Terhadap Kepuasan Kerja dan Komitmen Karyawan Pada Universitas Terbuka. Jurnal Organisasi dan Manajemen.Volume 8No.2.hal.121-134

[5] Edi Saputra Pakpahan, Siswidiyanto, Sukanto.Vol 2. Pengaruh Pendidikan Dan Pelatihan Terhadap Kinerja Pegawai (Studi pada Badan Kepegawaian Daerah Kota Malang). Jurnal Administrasi Publik (JAP). No 1. Hal 116- 121

[6] Gouzali, Saydam, 2005. Manajemen Sumber Daya Manusia: Suatu Pendekatan Mikro. Jakarta: Djambatan

[7] Gomes, Faustino Cardoso. 2003. Manajemen Sumber Daya Manusia, Edisi kedua.Penerbit Andi. Yogyakarta

[8] Hasibuan, Malayu. 2013. Manajemen Sumber Daya Manusia. Jakarta: PT. Bumi Aksara

[9] Hardjana, Andre. 2006. Iklim Organisasi:Lingkungan Kerja Manusiawi. Jurnal Ilmu Komunikasi.Volume 3. No.1 hal 1-36

[10] Ida Ayu Brahmasari.2009. Pengaruh Budaya Organisasi, Kepemimpinan Situasional dan Pola Komunikasi terhadap Disiplin Kerja dan Kinerja Karyawan pada PT Central Proteinaprima Tbk.Jurnal Aplikasi Manajemen Vol. 7 No. 1

[11] Kamuli, Sukarman. 2012. Pengaruh Iklim Organisasi terhadap Produktivitas Kerja Pegawai Di Sekreatariat Daerah kota Gorontalo. Jurnal Inovasi. Volume 9. No. 1 
[12] Kusumo, B.C.S. (2006). Hubungan Antara Persepsi Terhadap Iklim Organisasi dan Kepuasan Imbalan Kerja Dengan Loyalitas Kerja Pada Karyawan. Surakarta: Fakultas Psikologi Universitas Muhammadiyah Surakarta

[13] Lubis, M.Saleh. 2015. Pengaruh Iklim Organisasi dan Komitmen Organisasi Terhadap Pembentukan Organizational Citizenship Behavior (OCB) Karyawan Dalam Rangka Peningkatan Kinerja. Jurnal Apresiasi Ekonomi Volume 3 No. 2 hal 75-84

[14] Lupiyoadi, Rambat dan Hamdani, 2011. Manajemen Pemasaran Jasa. Jakarta: Salemba Empat

[15] Mangkunegara, AA. Anwar Prabu.2000. Manajemen Sumber Daya Manusia.Rosda Karya. Banduung

[16] Pace, R. Wayne dan Faules, Don F. 2018. Komunikasi Organisasi. PT. Remaja Rosdakarya: Bandung

[17] Rahmawati, Desi. 2013. Pengaruh Motivasi Terhadap Produktivitas Kerja Karyawan Pada PR Fajar Berlian Tulungagung. Jurnal Universitas Tulungagung BONOROWO Vol. 1.No.1

[18] Rao, TV. 2013. Performance Apprasial: Theory and Practise. Diterjemahkan oleh Ny. L. Mulyana. Penilaian Prestasi Kerja: Teori dan Praktek. Jakarta Pusat: Pusat Lembaga PPM dan Pustaka Binaman Pressindo.

[19] Robbins, Stephen P. 2002. Prilaku Organisasi. Alih Bahasa HandayaniPujaatmaka dan Benyamin Molan. Edisi ke delapan Jilid ke dua. Prehallindo. Jakarta.

[20] Runtu, Julius, 2013. Whistleblowing sebagai Ungkapan Loyalitas Karyawan: Pe- ran Employability dan Keberanian Moral Karyawan. (Online). (http://juliusruntu. blogspot.co.id/2014/02/indicator loyalitas-karyawan- bahan.html).

[21] Schermenharn, John R. 2003. Manajemen. Edisi Bahasa Indonesia. Penerbit Andi.Yogyakarta.

[22] Sinungan, Muchdarsyah.2003. Produktivitas apa dan Bagaimana. Bumi Aksara.Jakarta

[23] Sopiah. 2008. Perilaku Organisasional. Andi Ofset. Yogyakarta

[24] Utomo, B. (2002). Menentukan Faktor faktor Kepuasan Kerja dan Tingkat Pengaruh Kepuasan Kerja Terhadap Loyalitas Karyawan PT P. Jurnal Manajemen \& Kewirausahaan,Vol. 7 (2), 171-188.

[25] Vannecia Marchelle Soegandhi. Eddy M. Sutanto. dan Roy Setiawan. 2013. Pengaruh Kepuasan Kerja dan Loyalitas Kerja Terhadap Organizational Citizenship Behavior pada Karyawan pt. Surya Timur Sakti Jatim. Jurnal AGORA Vol. 1 No.1

[26] Sulistiyani, Ambar Teguh fdan Rosidah.2009. Manajemen Sumber Daya Manusia Edisi Kedua Cetakan Pertama. Garaha Ilmu. Yogyakarta 
[27] Wahid, Syafruddin. 2016. Komunikasi pada Lembaga Pendidikan Non Formal Suatu Kajian dalam Latar Budaya Minangkabau. Kencana. Jakarta.

[28] Wirawan.2007. Budaya dan Iklim OrganisasiTeori Aplikasi dan Penelitian.Salemba Empat. Jakarta

[29] Yanti Budiasih. 2012. Struktur Organisasi, Desain Kerja Budaya Organisasi dan Pengaruhnya Terhadap Produktivitas Karyawan Studi Kasus Pada PT. XX di Jakarta. Jurnal Liquidity Volume 1 No.2 hal 99-105 